\title{
DEVELOPMENT OF MICROPROCESSOR LEARNING MEDIA USING ZILOG Z-80 FOR VOCATIONAL SCHOOL STUDENTS OF ELECTRONIC ENGINEERING EXPERT PROGRAM
}

\author{
Nurul Fitri Fathia \\ Universitas Negeri Jakarta \\ Ivan Hanafi \\ Universitas Negeri Jakarta \\ Muhammad Rif'an \\ Universitas Negeri Jakarta
}

\begin{abstract}
This development research aims to develop microprocessor learning media using Zilog Z80. The Learning Media quality is based on the following aspects: (1) media feasibility according to subject matter experts and media experts; (2) effective based on students ability test by pre test and posttest. The developed cycles and procedures refer to the ADDIE model (analysis, design, development, implementation, and evaluation). This development research produces learning media as microprocessor kits training and e-Learning namely " $\mu$ Prosessor" as learning support. Data analysis techniques to test the effectiveness of learning media using Paired Samples T-Test and Using a Likert scale to test the feasibility of learning media. The research results show that the feasibility of learning media is enough with a high score of above 88\% and Paired Samples Test results for media effectiveness show an increase in the value of significant microprocessor capabilities. Measuring the improvement of the ability of students' microprocessors using $N$-gain (normalized gain). The results of the calculation of $N$-gain in the large group is 0.72 in the high category. Interpretation of the results of the research can be concluded that effective learning media as a learning media for microprocessors.
\end{abstract}

Keywords: learning media, research and development, ADDIE model, microprocessors

Permalink: http://dx.doi.org/10.21831/jpv.v8i3.20795

Contact Nurul Fitri Fathia nurulfathia23@gmail.com

- Universitas Negeri Jakarta, Jl. Rawamangun Muka,

RT.11/RW.14, Pulo Gadung, Jakarta Timur, DKI Jakarta 13220, Indonesia 


\section{INTRODUCTION}

Almost everything related to human activities was assisted by computers. Electronics is the basis of this machine. To understand how the computers work, we must have understood the basis of a computer system, there is a microprocessor. In the microprocessor system, there are sub-system blocks that are integrated to become a complete system. The microprocessor system is one of the subjects in Vocational High Schools (SMK). In Curriculum 2013, microprocessors become subjects with lots of material but have a little study time. Where the microprocessor subjects are given together with other materials, namely basic programming and microcontroller, but only have 3 hours/week of study time. To be able to achieve the learning objectives and the completion of everything that is available, the teacher must find effective and efficient ways to carry out learning. One of the training kits is MPF-1 with the Zilog Z-80.

In ideal learning, there will always be an interaction between teachers and students. Because teachers and students are two elements that are in the learning environment and utilize learning resources. Related to the interaction between teachers and students, students' perception of the teacher's ability to teach and use learning resources such as learning media can be used as material for feedback on the quality of teaching and the ability of teachers to use learning media (Sutrisno \& Siswanto, 2016, p. 113).

Therefore, it is necessary to make an appropriate learning media so that it can help teachers and students.. According to Anggara based on observations that have been made on the subject of the microprocessor were lack of attention and not in accordance with the existing Basic Competencies. Therefore, by developing microprocessor learning, it is expected that vocational students can understand the working principle of microprocessor systems more easily (Anggara, 2016, p. 1038).

In addition, based on the results of Fathia's research that has been conducted on 11 Vocational School of Electronics Study Programs in Indonesia, it can be seen that the implementation of Microprocessor Learning in outline is not in accordance with the Core Competencies and Basic Competencies that exist. The contributing factors include: (1) In terms of infrastructure, microprocessor training kits are difficult to obtain. (2) In terms of the teacher, it was difficult to operate the microprocessor Training kits and had a view of the microprocessor was not important than the microcontroller so that it no longer needed to be taught, (3) In terms of students, more interested in simple and practical things such as microcontrollers (Fathia, 2017, pp. 511-512). Sarosa \& Khairudin (2016, p. 31) get the results of research that the right learning media can clarify the delivery of microprocessor material, guide users to independent learning, learning, and attract attention.

From the basis of previous studies, it can be concluded that the use of learning media is very important in microprocessor learning. By looking at the advantages and disadvantages as well as other factors in the previous research, the researcher will develop "Microprocessor Learning Media". The media is a training kit that is integrated with computers, so students get a variety of learning media in the form of presentations, animated videos, job sheets, simulations and practical work directly using training kit based Z80 microprocessor. Because if it is not supported by the right media, students will find it difficult to understand this material, especially the material is quite difficult and abstract. For an explanation of abstract material, an explanation is needed in a visual illustration, it will provide a faster understanding. Arsyad (2015, p. 11) says that the more the five senses are responsible for accessing and processing information, the greater this information is understood and stored in memory. This is an effort in maximizing the Core Competencies and Basic Competencies and making Training kits that is user-friendly both from the teacher and student side.

Wirawan, Indrawati, \& Rahmanto (2017, p. 85) state that the use of learning media is a very important factor to improve student learning outcomes in the learning process, because learning media is one of the tools that is very supportive in the development of knowledge possessed by a person, especially in the learning process at school. So that the school should pay attention to and provide a complete educational media so that the learning process in the classroom can run effectively because students are more motivated to learn if the lesson is explained with direct practice. 
There are three criteria that are used to determine the quality of a product learning media, they are valid, practical, and effective. The explanation of each aspect that will be used in the development of learning tools in this study is the following. The first is the validity aspect, said to be valid if the learning device is declared feasible to be used with revision or without revision by the teacher. Second is the practicality aspect, the learning device is said to be practical if students and teachers respond well to the use of learning devices. Third, the aspect of effectiveness, namely the learning device is said to be effective if students achieve the competencies that must be owned (Fatkhurrokhman, Permata, Ekawati, \& Rizal, 2017, p. 104).

Based on the background of the problems that are quite broad, it is necessary to focus on the research to be studied. Then the researcher will issue on: (1) Development of Learning Media Zilog Z80-based Microprocessor Systems include e-Learning and Zilog Z80 Training kits that are in accordance with Basic Competencies in Basic Programming Techniques, Microprocessors and Microcontrollers; (2) Implementation of microprocessor media in learning at Vocational High Schools in South Jakarta.

The use of Zilog Z80 microprocessor learning media is (1) Theoretically, the results of this study are expected to be used as learning media for Electronics Engineering Vocational students in understanding and deepening the workings of microprocessors from the entire process. (2) Practically, the results of this research can be a medium of learning in a variety of media that are numerous and support the improvement of user skills.

\section{METHOD}

This study uses Research and Development (R \& D) methods, The model used to design this project is the ADDIE Model. The ADDIE model is one of the systematic learning design models. One of the functions of ADDIE is to become a guideline in developing a learning media development design. This model in accordance with its name consists of five stages, there is a phase analysis, design phase, development phase, implementation phase, and the evaluation phase (Tegeh, Jampel, \& Pudjawan, 2014, p. 41). Evaluation is the most important part in the development of this model, where each stage is carried out a small evaluation related to the stage and the overall evaluation at the end of the stage. This model is simple and with a systematic structure. Five stages in the ADDIE interrelated and systematically structured means that from the first phase until the fifth phases in the application should be systematical. This step is suitable for the characteristics of the product research and development that was done (Hamid, Aribowo, \& Desmira, 2017, p. 153).

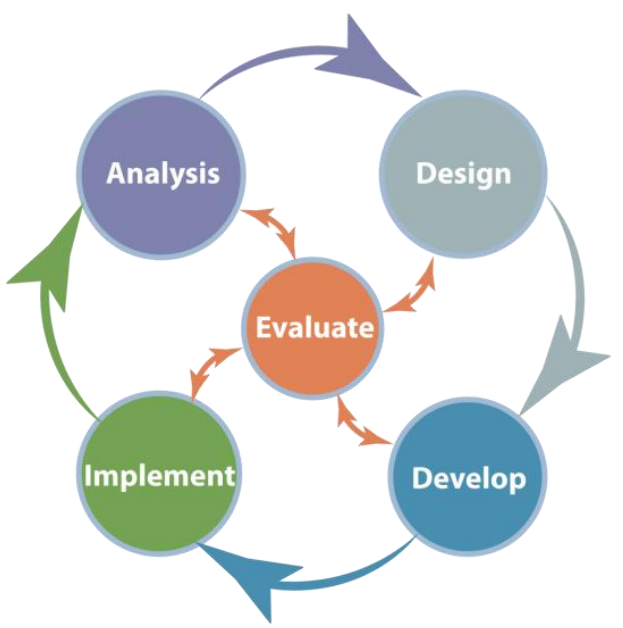

Figure 1. ADDIE Model Stages

This research was conducted at SMKN 29 Jakarta. This research was carried out in the second semester of the academic year 2017 2018. The Training kits trial was conducted in April - June 2018 for students of the Vocational School of Technology and Engineering in the Electronics Engineering Expertise Program in Industrial Electronics Engineering Skills Competence. The total number of students is 65 students who will be divided into large groups and small groups. Where $25 \%$ of all students become small groups and the other $75 \%$ become large groups.

Characteristics of the model developed in this study are the implementation of learning designed in the form of face-to-face presentation using learning media in the form of eLearning and Zilog Z-80 Microprocessor Training kits. This learning media is a microprocessor system that is developed with eLearning and Training kits integrated with computers so that we can more easily in the theoretical presentation process and in practical programming. 
Based on the foundation of the model development that has been chosen, ADDIE, in the design of the model, it is necessary to analyze the needs and conditions of the field related to the subject matter raised. Needs analysis and field conditions have been explained previously in the background. After doing the analysis and getting what needs to be developed, the next step is Model Design. The media development plan chart that will be made can be seen in Figure 2.

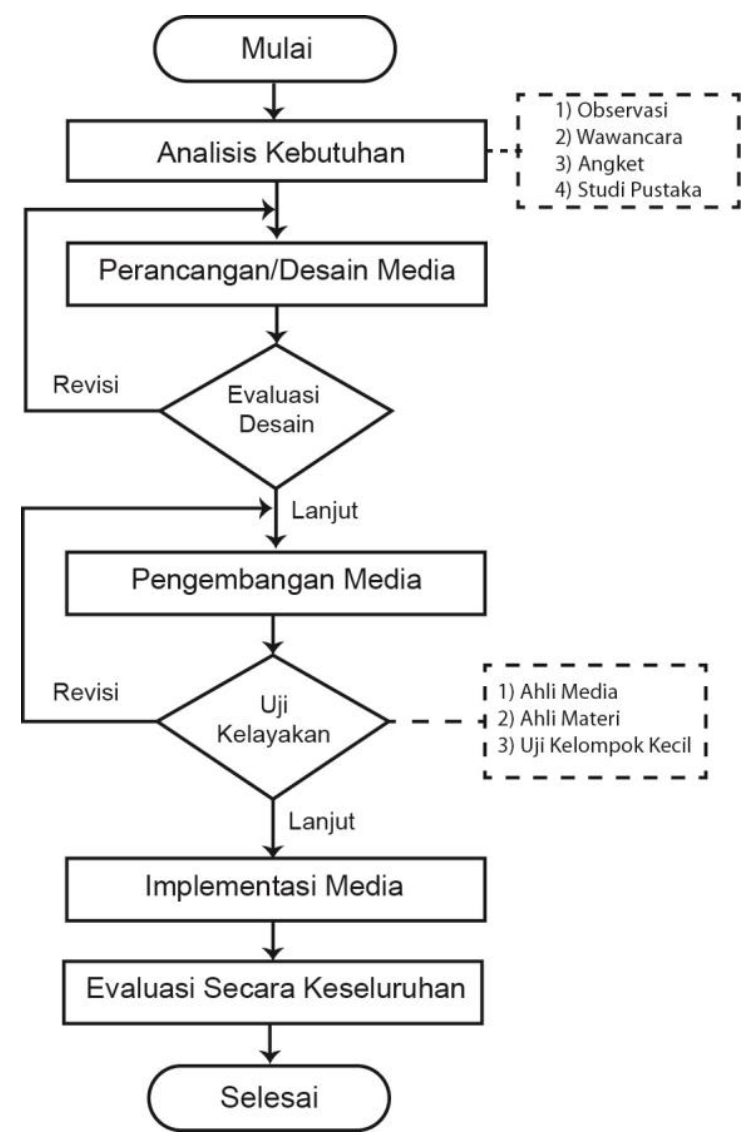

Figure 2. Chart of Media Development Plans

The Learning Model approach used is Project-based Learning. Project-based learning is a learning activity that uses projects/activities as a learning process to achieve competencies in attitudes, knowledge, and skills. The emphasis of learning lies in the activities of students to produce products by applying the skills of researching, analyzing, making, and presenting learning products based on real experience. The product in question is the result of the project in the form of Flowchart, Program and Model Tool that has been designed. This approach allows students to work independently or in groups to produce real pro- ducts. In general, this Training kits design can be seen in Figure 3 and Figure 4.

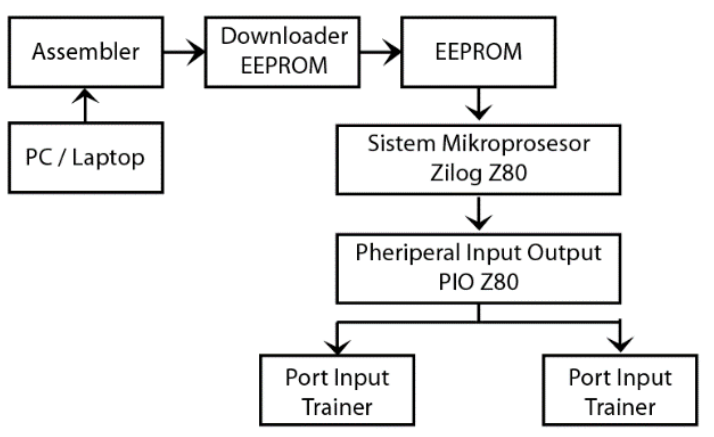

Figure 3. Block Model Design Diagram

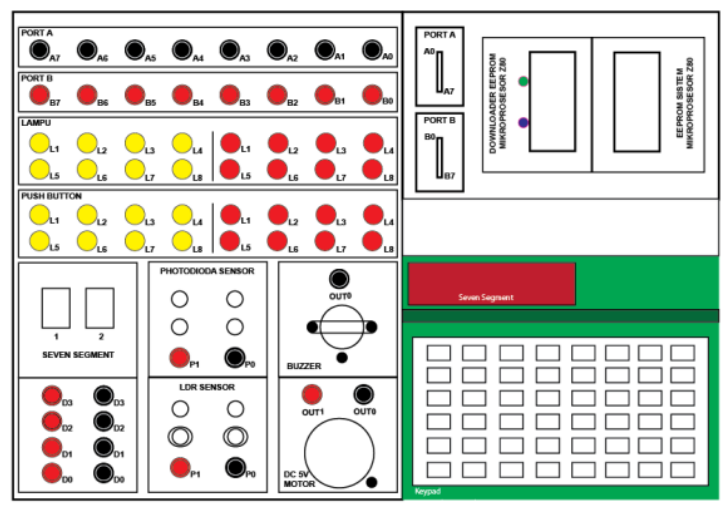

Figure 4. Looks for Microprocessor Training Kits

This research is a descriptive research that is developmental so that in this study is not intended to test certain hypotheses. The data analysis technique that was carried out in the first stage was to use qualitative descriptive, which was describing media products from the design of learning media after being implemented in the form of finished products and testing the level of product feasibility. The second stage uses quantitative descriptive, which describes the feasibility of the product to be implemented on competency standards. Understanding Microprocessor Architecture Vocational Middle School. This validation is carried out by study experts (material experts) and learning design experts (media experts). This validation instrument uses three references in the assessment, namely according to Azhar Arsyad, Rayandra Asyhar, and Romi Satrio Wahono.

Furthermore, the trial for Training kits quality and learning Training kits effectiveness as well as pretest and posttest in field trials. According to Moore D. Keneth in Moh Syarif 
the effectiveness of a measure that states how far the target (quantity, quality and time) has been achieved, or the large percentage of targets achieved, the higher the effectiveness (Sumantri, 2015, p. 1). The effectiveness of learning media is carried out during media implementation by using one-group pretest-posttest design, ie there is a pretest before being treated and posttest after being treated in the same group. To test the effectiveness of learning outcomes using the two average difference test for non-free samples. Prior to testing, a normality test is performed to determine the type of statistics to be used, whether parametric statistics or non-parametric statistics (Sugiyono, 2013, p. 172).

To see how much improvement in student learning outcomes, the pretest and posttest data can be analyzed to get gain and N-gain. Gain is the difference between the pretest and posttest values. To show the quality of increasing microprocessor knowledge and students' cognitive learning outcomes, the average normalized gain (N-gain) formula is used. N-gain (normalized gain) is used to measure the improvement of science process skills and cognitive learning outcomes between before and after learning (Sundayana, 2014, p. 151). The gain index can be calculated by the formula from Meltzer, namely:

$$
\begin{gathered}
(\text { Ngain })=\frac{\text { Posttest score }- \text { Pretest score }}{\text { Maximum Score }- \text { Pretest score }} \\
\text { Table 1. . Gain Index Category }
\end{gathered}
$$

\begin{tabular}{cc}
\hline Perolehan N-Gain & Kriteria \\
\hline N-Gain $>0,70$ & Tinggi \\
$0,30 \leq \mathrm{N}-$ Gain $\leq 0,70$ & Sedang \\
N-Gain $<30$ & Rendah \\
\hline
\end{tabular}

(Duda, 2010, p. 31)

\section{RESEARCH RESULTS AND DISCUSSION}

\section{Analysis Phase}

At this stage, the analysis phase involves several determining processes and identifies the problems that need to be resolved.

The selection of microprocessor subject matter is based on the analysis carried out found three fundamental things in the development of microprocessor learning media, there are: (a) in terms of infrastructure, microprocessor Training kits are rare; (b) in terms of the teacher, it was difficult to operate a microprocessor Training kits and had the view that the microprocessor was not important than a microcontroller, so the microprocessor there was no need to be taught; (c) in terms of students, they are more interested in simple and practical things like microcontrollers.

It is known that the 2013 curriculum requires students to do more practicum with a comparison of $30 \%$ theory and $70 \%$ practicum. Therefore, complementing some of the shortcomings of previous studies, the authors compiled a microprocessortraining kits consisting of a microprocessor system, downloader EEPROM, and an input-output device. To supporttraining kits usage more leverage and more organized learning, for offline e-Learning that students can use on their laptops or in school laboratories. In addition, a video tutorial is provided to facilitate students in the programming learning process, because it is known that there are quite a number of students and practicum teachers who are only one problem in various vocational schools. Therefore, the teacher assistant assistant is needed, in the form of a customized video tutorial so students can follow it directly. That way learning is expected to be more effective because of the reduced time to ask repeatedly about the learning.

\section{Design Phase}

At this stage of the process, it explains the overall view of the design, structure, teaching approaches, types of media and technologies to be used. At the design stage, the authors compile the media according to the needs analysis that has been done.

\section{e-Learning $\mu$ processor}

The name of e-Learning is $\mu$ processor, e-Learning is made offline and can be used by installing it on a computer device. In e-Learning, there are 4 main learning titles that represent 4 Basic Competencies in the subject of Programming Basics, Microprocessors and Microcontrollers. There are 3 main parts of eLearning, namely, subject matter, simulation, and practicum.

\section{Microprocessor training kits}

MPF-1 deficiency as a previous microprocessor training kits is the location of ports A and Port B that are not sequential, the prog- 
ram is stored in RAM which will be lost if the power flow is off, programming is done by typing using the keypad and will take a long time and the possibility of writing errors during the program the process of filling in the program code. For this reason, the training kits were developed with MPF-1 as a basis and complemented the deficiencies in MPF-1, they are: (1) utilizing the EEPROM Port as a place to store the program, so that it will not affect if the power supply is off; (2) use the EEPROM downloader to load programs into EEPROM, to shorten the time and reduce the possibility of errors in filling in the program code; (3) arrange PIO ports which are Port $\mathrm{A}$ and Port $\mathrm{B}$ regularly; (4) adding Input-Output devices as training kits complement, in the form of Led, Pushbutton, Light Sensor, Seven Segment, DC Electric Motor and Buzzer

The size of the training kits is designed to be lightweight and portable while still providing good clarity for the user. Then it was made with a size of $27 \times 42 \mathrm{~cm}$ so it wasn't too big. Components are arranged regularly to facilitate usage with the help of the writing displayed in each component part.

\section{Development Phase}

This stage involves real system implementation by using all appropriate media and technology elements based on requirements Built based on the analysis phase and the design phase.

This stage of learning media development is the stage where the design results at the design stage are realized in real form. In this stage, the author makes 2 main parts, e-Learning and the microprocessor Training kits. For the main menu display of e-Learning Microprocessor can be seen in Figure 5, for the contents of the menu can be seen in Figure 6 and for examples of material contents can be seen in Figure 7.

e-Learning is expected to help the teacher in delivering the material easier and help students understand the material with their respective learning styles, which can be done visually or audio-visual by watching the video tutorial provided repeatedly so that they can understand it.

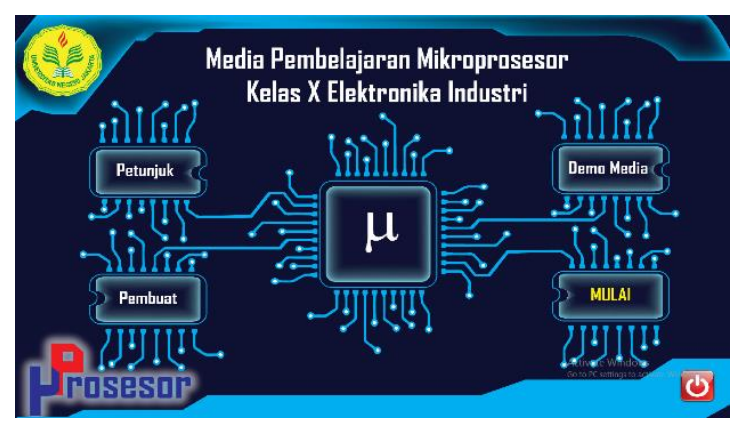

Figure 5. Initial Display of e-Learning $\mu$ Processor

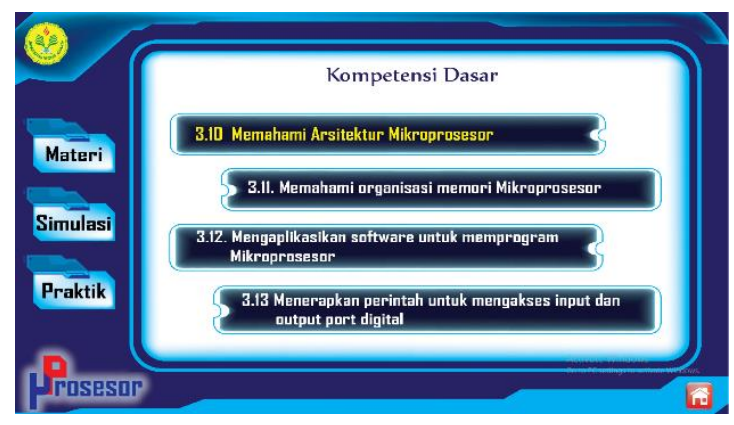

Figure 6. Display Contents of e-Learning Menu $\mu$ Processor

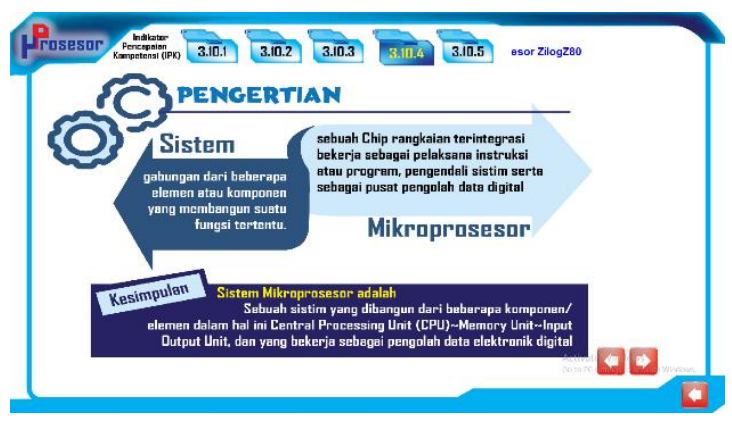

Figure 7. Display contents of e-Learning material $\mu$ processors

For Training kits $\mu$ processors use MPF1 as the main board and are equipped with input-output devices as previously designed. The assembly results of the Training kits can be seen in Figure 9. for the top view, figure 10 for the rear view, and figure 11 for the side view. In this processor $\mu$ processor, can organize inputs and outputs through two ports, namely Port A and Port B, which can be set as input or output. The connector used in this Training kits uses a banana jack to make it easier for students to connect between input-output ports and devices. 


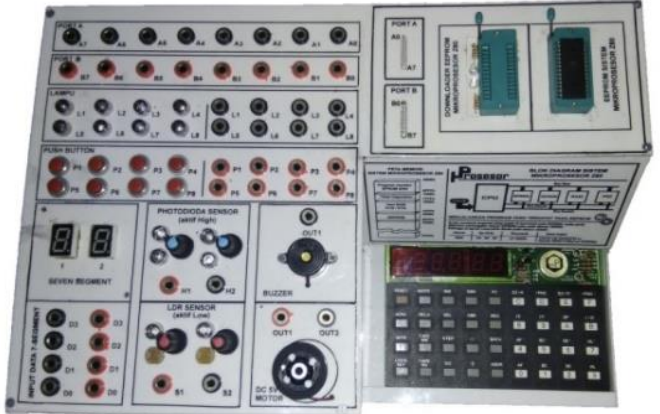

Figure 8. Appears on the Processor $\mu$ Processor

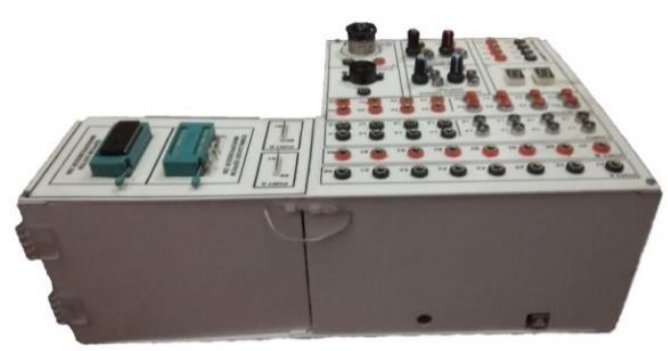

Figure 9. Rear view of the Processor $\mu$ Processor

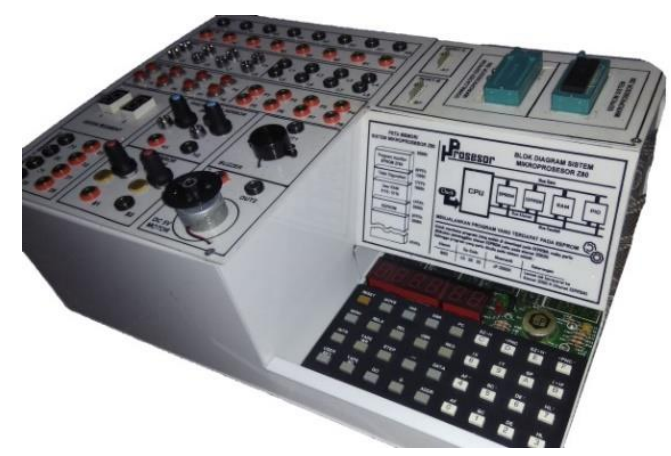

Figure 10. Side View of the Processor $\mu$ Processor

\section{Implement Phase}

At this stage, the learning media that have been prepared will be used or implemented in real terms. In this phase, testing was also made. Learning was conducted in 5 meetings for learning material and 2 meetings for pretest and posttest. During the small group trial conducted on 16 students. For the implementation of this microprocessor learning media, it is carried out in large classes with a total of 49 students. In this implementation, the media that has been created is used as a learning support media in accordance with the learning plan that has been made. Before the media is implemented, the media must be tested for feasibility. The feasibility testing phase of learning media was conducted to see the level of validity of media use. This validation test consists of content validation and constructs validity. Content validation data was obtained through material experts while contract validation data was obtained from media experts. Material validation test results on $92 \%$ conformity aspects, $88 \%$ completeness aspects, $92.5 \%$ ease and $92.5 \%$ clarity. Media expert validation test results on communication and interactive aspects 93\%, 95\% suitability, 95\% complete aspects, and 90\% ease.

\section{Evaluate Phase}

This phase is an advanced phase of the implementation phase. The revision of the microprocessor learning media is done at the expert review stage and small group trials. In the Evaluation stage, the pretest and posttest tests were conducted and then compared the results. The calculation result of Gain in the small group is 48.19 with the $\mathrm{N}$-gain index in the small group is 0.72 in the high category.

For the results of calculating large group data, the average value of the pretest of the microprocessor's ability before being carried out by the researcher is 30.41 . The average posttest value of the microprocessor's ability is 79.96. The gain value of microprocessor capability is 49.55 . The $\mathrm{N}$-gain value of problemsolving ability is 0.71 .

To see whether there is an increase in the ability of the microprocessor for students between pretest and posttest on the microprocessor, it is necessary to test hypotheses using parametric statistical tests because the data obtained are normally distributed. Testing is carried out using a paired sample t-test. Testing criteria if the significance value $<0.05$ then $\mathrm{Ha}$ is accepted and Ho is rejected, while if the significance is $>0.05$ then $\mathrm{Ho}$ is accepted and $\mathrm{Ha}$ is rejected. the result of different test the value of the microprocessor ability between pretest and posttest was obtained by Sig. (2-tailed) of 0,000, because Asymp. Sig. (2-tailed) $<0.05$ then $\mathrm{Ha}$ is accepted and $\mathrm{Ho}$ is rejected, so it can be concluded that there is an increase in the value of the microprocessor ability between pretest and posttest before and after learning.

\section{Discussion}

The microprocessor subject to date is a basic subject for understanding digital techniques at the vocational high school level in 
electronic competence. In developing instructional media $\mu$ Processors that have been carried out in the form of Training kits and eLearning are improvements from the previous Training kits, MPF-1. In addition, the results of the development of learning media also pay attention to the advantages and disadvantages of previous related studies. The research was conducted by N. Topalaglu and O. Gürdal from Turkey in 2010, where they made microprocessor learning media to study microprocessor architecture and Assembly programming language. The result is that the media can help students well in understanding the architecture and programming of microprocessors but limited to the simulator. From this study, the authors developed this learning media equipped with e-Learning with the aim of making it easier for students to understand theoretically the microprocessor as already done by $\mathrm{N}$. Topalaglu and O. Gürdal. Subsequent research conducted by Doni Sarosa and Moh. Khairudin in 2016, developed an interactive learning media which broadly had the same objectives as N. Topalaglu and O. Gürdal, where the media contained microprocessor material with a wider scope, which included the main material, introduction, history, benefits, basic microprocessor, and the basic components of the microprocessor. However, as with previous studies, this study is limited to aspects of student knowledge. In connection with this, the author develops learning media that can help students understand microprocessor material with e-Learning and adapted to Basic Competencies in the revised Curriculum 2013. Basic competencies in the Curriculum 2013 consist of cognitive aspects with initial code 3 and psychomotor aspects with initial code 4 . Therefore, the authors develop media in the form of material that is designed visually attractive and also in the form of videos for the development of cognitive aspects. For the skills aspect, the author developed a job sheet related to existing basic competencies. For more details, can be seen in Figure 11. for cognitive aspects and Figure 12 for psychomotor aspects.

It is undeniable, the use of simulators is very important, given the small number of learning Training kits and the expensive price, the simulator becomes one of the solutions of it all. In addition, using simulators students can practice in their homes at any time to get used to the microprocessor and get a complete basic knowledge of $\mu \mathrm{P}$ in the same programming mode (Nas, 2014, p.47). Therefore, this learning media uses several complementary software, including Z80 Simulator IDE, HxDHexeditor, and write EEPROM. The three software are used throughout learning in several parts of competence, one of them is when the process of programming and downloading programs into EEPROM. The appearance of the software can be seen in Figure 13.

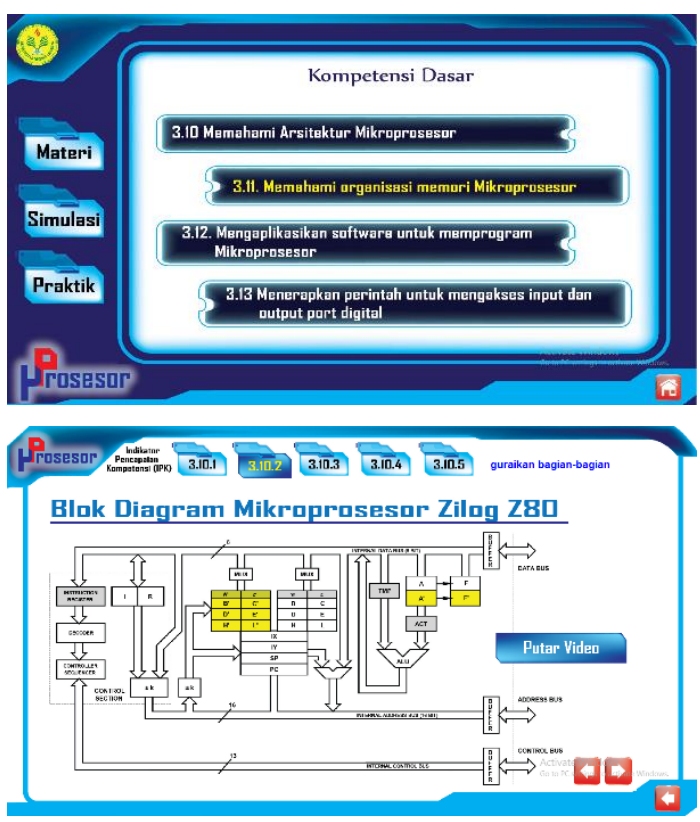

Figure 11. E-Learning Display $\mu$ Processor on Cognitive Aspect Material

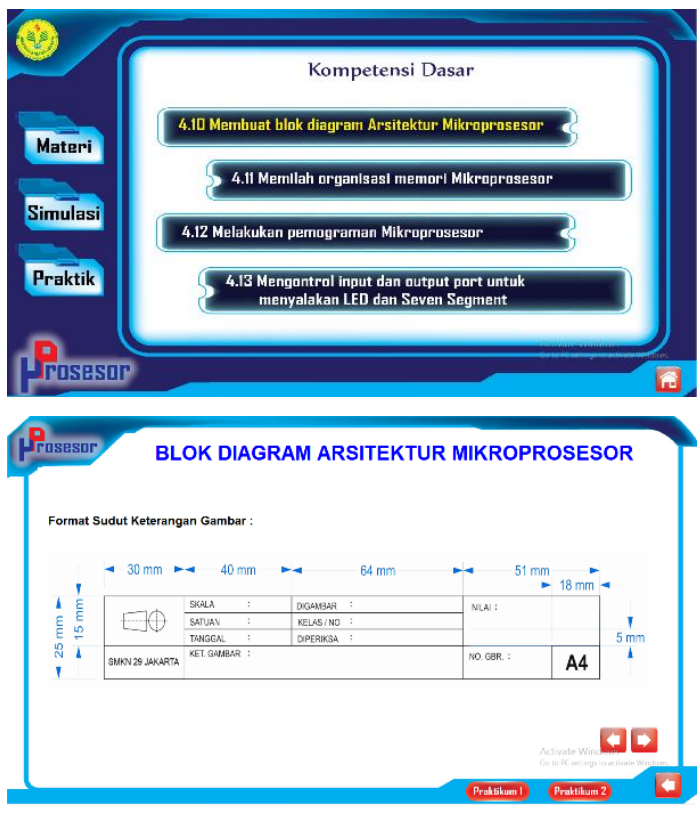

Figure 12. E-Learning Display $\mu$ Processor on Psychomotor aspects of Practice 


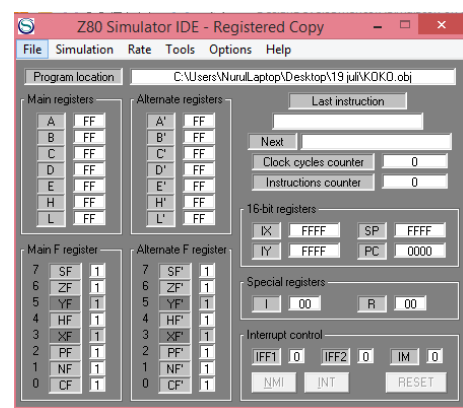

(a)

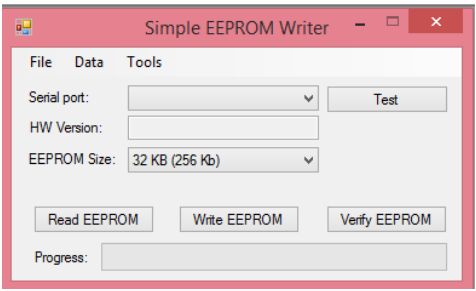

(b)

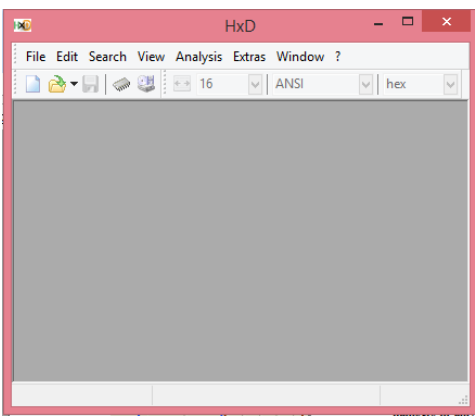

(c)

Figure 13. (a) 80 Simulator IDE, (b) HxDHexeditor, dan (c) eewrite EEPROM.

Anggara in 2016, made a research related to the making of the 8088 Microprocessor System simulator based on Arduino Uno, where students were generally taught how to work from the microprocessor RAM write process. But the system created in this Training kits is not a system that uses one of the microprocessors but uses an Arduino Uno microcontroller. In addition, the Training kits created is not designed to study accessing input and output ports. Accessing input and output ports itself is one of the Basic Competencies expected by students of Industrial Electronics Competency Vocational School. Based on the basic competencies applied in the Curriculum 2013 revised, the authors develop microprocessor Training kits that can access the input-output port and executing a program with input-output devices that are also provided. Accessing inputoutput ports in the learning media that I developed can be seen in Figure 14. In addition to complementing the short-comings of MPF-1 as a learning medium be-fore, this media allows students to store prog-rams in EEPROM, so it does not take long in charging the program into RAM using the Keypad and no need to worry about the sudden power outage. Because if the program is filled in RAM, the program will automatically be erased if there is a power outage. The EEPROM downloader system that is used uses the help of Arduino MEGA and an rewrite program that allows, we can write a hex code into the EEPROM. To see the form of downloader EEPROM can be seen in Figure 15.

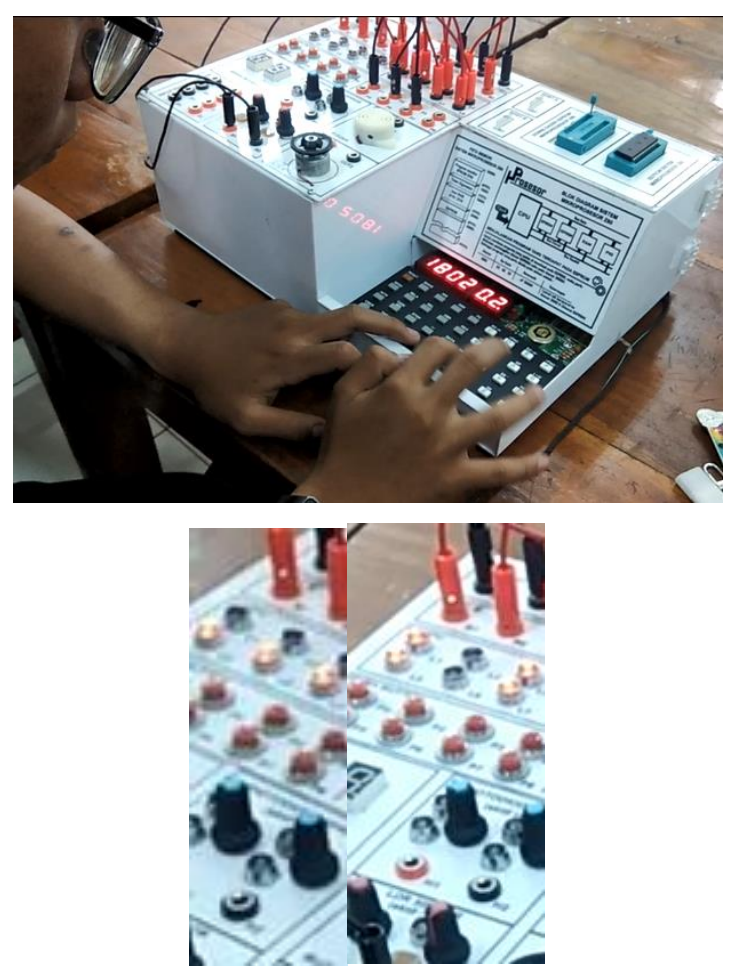

Figure 14. Accessing the Input-Output Port on the $\mu$ Processor Training kits

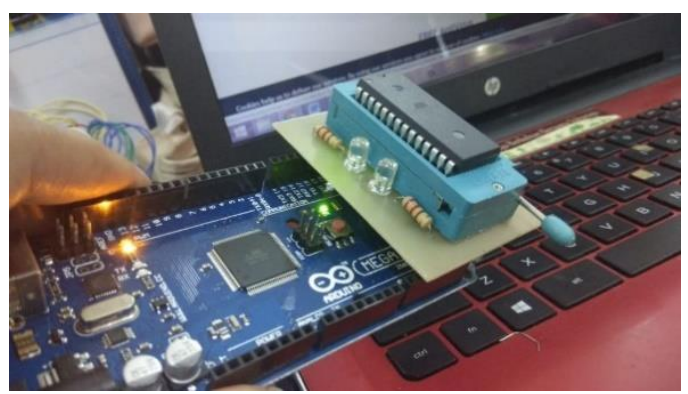

Figure 15. Download the EEPROM on the $\mu$ Processor Training kits

Besides being equipped with downloader, Training kits $\mu$ Processor there is an inputoutput device which consists of 8 LEDs, 8 
Pushbutton pieces, 2 seven-segment pieces, 2 types of light sensors with 2 control signals namely LDR for high active and Photodiode for low active, 1 Buzzer and $1 \mathrm{dc}$ motor that can be controlled in both directions.

\section{CONCLUSION}

Based on the research results obtained in the development of microprocessor learning media, it can be concluded as follows:

Fisrt, In developing the microprocessor learning media using the ADDIE model, with the stages of Analysis, Design, Development, Implementation and Evaluation. Media trials are carried out with small groups and large groups. The trial process was carried out as many as seven meetings. From the results of this study, it can be said that the microprocessor learning media using Zilog Z80 can support the implementation of learning.

Second, data on improving student learning outcomes can be seen from the pretest that was done before learning and posttest after learning. Testing the media using Wilcoxon while increasing the learning outcomes is used $\mathrm{N}$-gain. From the results obtained, this learning media is considered effective in improving student learning outcomes in microprocessor lessons.

This microprocessor learning media can be implemented as one of the alternative media in the implementation of students' theoretical and practical learning. The use of microprocessor learning media can help students improve their cognitive and psychomotor abilities.

Based on the process and results of developing microprocessor learning media, the authors can suggest the following: (1) conduct further research from more diverse learning resources and wider practical material, (2) it is expected that the peneti is then able to develop this media in one complete software without the help of other program software, (3) The role of teachers and schools is needed to maintain and develop existing learning media. In addition to utilizing all the learning media in the school to the maximum and tailored to the needs of Basic Competencies.

\section{REFERENCE}

Anggara, R. A. (2016). Rancang bangun simulator minimum system mikroprosesor 8088 berbasis Arduino

Uno sebagai media pembelajaran

Mikroprosesor di Jurusan TITL SMK

Raden Patah Kota Mojokerto. Jurnal

Pendidikan Teknik Elektro UNESA, 5(3).

Arsyad, A. (2015). Media pembelajaran.

Jakarta: PT Raja Grafindo Rersada.

Duda, H. J. (2010). Pembelajaran berbasis praktikum dan assesmennya pada konsepsisten eksresi untuk meningkatkan kemampuan berpikir kritis mahasiswa Kelas XI. VOX Edukasi, 1(2).

Fathia, N. F. (2017). Analisis pengunaan training kits MPF-1 pada pendidikan abad 21. In Prosiding 21st Century Trends And Innovations In Education Endeavor: Integrating 21st Century Skills Into Practice. Yogyakarta: UNY Press.

Fatkhurrokhman, M., Permata, E., Ekawati, R., \& Rizal, S. U. (2017). Pengembangan perangkat pembelajaran teknik digital berbasis project based learning di jurusan pendidikan teknik elektro. Jurnal Pendidikan Vokasi, 7(1), 101-109.

https://doi.org/10.21831/jpv.v7i1.12547

Hamid, M. A., Aribowo, D., \& Desmira. (2017). Development of learning modules of basic electronics-based problem solving in Vocational Secondary School. Jurnal Pendidikan Vokasi, 7(2), 149-157. https://doi.org/10.21831/jpv.v7i2.12986

Sarosa, D., \& Khairudin, M. (2016). Pengembangan media pembelajaran interaktif pada mata pelajaran mikroprosesor di SMK Negeri 2 Pati. $E$ Journal Universitas Negeri Yogyakarta, 6(1).

Sugiyono. (2013). Cara mudah menyusun: skripsi, tesis, dan disertasi. Bandung: Alfabeta.

Sumantri, M. S. (2015). Strategi pembelajaran: teori dan praktik di tingkat pendidikan dasar. Jakarta: PT Raja Grafindo Persada.

Sundayana, R. (2014). Statistika penelitian pendidikan. Bandung: Alfabeta. 
Sutrisno, V. L. P., \& Siswanto, B. T. (2016).

Faktor-faktor yang mempengaruhi hasil belajar siswa pada pembelajaran praktik kelistrikan otomotif SMK di Kota Yogyakarta. Jurnal Pendidikan Vokasi, 6(1), 111

https://doi.org/10.21831/jpv.v6i1.8118

Tegeh, I. M., Jampel, I. N., \& Pudjawan, K. (2014). Model penelitian pengembangan. Yogyakarta: Graha Ilmu.

Wirawan, A. W., Indrawati, C. D. S., \& Rahmanto, A. N. (2017). Pengembangan media pembelajaran kearsipan digital untuk meningkatkan hasil belajar siswa SMK Negeri 3 Surakarta. Jurnal Pendidikan Vokasi, 7(1), 78. https://doi.org/10.21831/jpv.v7i1.12879 